\title{
QUALITY SERVICE DELIVERY AND STUDENTS' SATISFACTION IN PUBLIC UNIVERSITIES IN SOUTH EASTERN NIGERIA
}

\author{
OKPA, O.E. \\ Department of Educational Administration and Planning \\ University of Calabar, Calabar
}

\begin{abstract}
This study investigated the relationship between quality service delivery and students satisfaction in public universities in South Eastern Nigeria. Descriptive survey research design was adopted for the study. The population comprised 1,231 final year students. Simple random sampling technique was used to select 200 final year students as sample for this study. Data were collected with the aid of a questionnaire titled: Service Delivery Quality and Student Satisfaction Questionnaire (SDQSSQ). The questionnaire was validated by some experts. Cronbach Alpha method of reliability was used to determine the reliability of the instrument. The reliability value stood at $r=0.72$. The questionnaire was tested using descriptive statistics and Pearson Product Moment Correlation Coefficient. The result of the study showed a significant positive relationship between quality teaching, curriculum, academic advising, and physical facilities and students' satisfaction. It was recommended among others that, University management should be more proactive towards infrastructural development and in providing adequate facilities for students to enhance their work as well as create good learning environment.
\end{abstract}

Keywords: service delivery, quality, universities, satisfaction

\section{INTRODUCTION}

The university is a service institution that develops the human person and advances human civilization. A university is the expression of the needs of a community, a society or a nation. It is devoted to the fashioning of its intellect. Universities are created to satisfy specific or general educational needs of a nation through teaching of students, conducting of research and dissemination of knowledge together with other community service activities. In fact, universities have a

commitment to active participation in social transformation, economic, economic modernization and the training and upgrading of the total human resources of the nation (Soludo, 2013).

Universities in Nigeria are experiencing competitive pressures resulting from the reduction in government financial support. They are being encouraged to place a renewed focus on meeting or exceeding the expectations and needs of their customers by developing enterprising approaches to revenue generation, and a commercial orientation towards the provision of teaching and student services. In today's service oriented economy, excellent service is more than a competitive weapon - it is a survival skill. Customers (that is, all users of the university - students, their parents, alumni, employers and staff members) to the universities especially students are gradually becoming aware of their right to quality service delivery as far as their studies is concerned. As a result, the provision of quality services in the universities is gaining strength and has made many stakeholders in the education industry, to place much premium on unprecedented quality service delivery as a means to eradicate hostile effects and to meet consumer's numerous demands while fostering real value for their money.

The universities are equally experiencing vital changes in the way they operate and interact with their 'customers. Since competition has increased amongst service-minded educational institutions, the quality of the service is therefore crucial for universities in order to satisfy and maintain its customers. Students are demanding more attention and instant service and so proactive universities are emphasizing service delivery quality and customer relationship management systems 
International Journal of Engineering Applied Sciences and Technology, 2019

Vol. 4, Issue 5, ISSN No. 2455-2143, Pages 100-107

Published Online September 2019 in IJEAST (http://www.ijeast.com)

- to cater for this demand in an effective way. Satisfied students have greater tendency to continue consumption, spread positive views or increase word of mouth recommendations to yield new customers without extra cost on marketing the institution. The reverse is true as an unfulfilled expectation inevitably leads to dissatisfaction.

The concept of service can be defined as an intangible product that cannot be owned or stored, but it comes to existence at the time and place it is delivered for consumption (Green \& Ramroop, 2014). Service delivery is about delivering services as effectively and efficiently as possible to the satisfaction of the customer. According to Parasuraman, Zeithaml and Berry (1985) service delivery is a measure of how well the service level has been achieved, or matches customer expectations. This definition is echoed by Zeithaml (1988) who states that service delivery reflects the opinion the customer has regarding the superiority of a product or service. In his research on service delivery Pupo (2010) highlights the customer factor by claiming that 'there is no better proxy for the long-term economic potential of a business than the strength of the customer satisfaction ratings' (p.5). In higher education context according to a study by Tait and De Jager (2009) students are regarded as the primary customers. Their experiences as customers take place internally (internal customers) and are based on the assessment of all the critical components of the education system, including inputs as well as outputs. In recent times, service delivery efficiency is driven by outcome assessment, which requires measuring the desired results of a particular instructional or education effort that is more strongly directed to the learning process. Other service delivery outcomes include the assessment of quality in teaching and learning and measuring the quality of the total student experience (van der Westhuizen, 2014).

Service delivery is the capability and having the right infrastructure of delivering services correctly according to a particular standard and with consistency. It covers the help, assistance and services academic staff are required to give to students, parents, users of the university and the community. Service delivery can be also conceptualized as the relationship between policy makers, service providers and consumers of services, and encompasses both services and their supporting systems (Slaymaker, Christiansen \& Hemming, 2005).

Quality service delivery is the top priority in public universities if the goal of university education must be achieved. Strengthening the provision of essential services can also contribute to the long-term process. Service delivery underpins the contract between academic staff and all university users and, as such, is an indicator of the health of a society. A service is effective whenever its outcomes or accomplishments are of value to its customers; and is efficient when the same goals are achieved using available resources. Public access to good services indicates that a society is well-governed and enables the political leadership to draw continued support for its programme. Different groups in society will have different visions about what makes "good" service delivery. In the education sector for instance, clients (parents, learners, alumni, staff members,) want low-cost, easy-to-access, safe, highquality schooling that improves their children's/their life chances. Policy makers and political leaders want to deliver social benefits at low cost, with high propaganda value and political rewards. The providers (lecturers/teachers/administrative and other staff) care about technically sound curricula, adequate incentives, high salaries, respect and safety. Thus, the effectiveness of service delivery depends on addressing competing goals and expectations in ways that satisfy the stakeholders.

Services reach the public in a two-step process: allocation (by policymakers) and production (by service providers/implementers). Accountability between the policy maker and the implementer is defined by a compact, which includes service delivery standards, monitoring methods, rewards and sanctions. This service compact cannot fully specify outcomes, especially for services that are inherently transactionintensive and hard to monitor (such as classroom education). One element of quality management consist of shaping the expectations of the client(students) and preparing them to enter the interaction in such a way as to contribute as much as possible to the social dynamics that engenders his own quality experience. Clients participate in the selling or marketing of the service to other clients. This is done by word of mouth or by formal reference. Because of the special characteristics of services, a good reference from a positive client is always a particularly valuable marketing tool, both for services to individuals and for professional services to the institutions.

Satisfaction is a state felt by a person who has experienced a performance or an outcome that fulfill his or her expectation. Satisfaction can also be said to cover students' perception and experiences during the college years. Student satisfaction is students' disposition by subjective evaluation of educational outcomes and experience. It is a function of relative level of experiences and perceived performance about educational service during the study period (Elliot \& Shin, 2001). This paper explores the role of service delivery quality in the academic life of undergraduates. 
It focuses on students' satisfaction on services provided by the universities in the form teaching quality, curriculum, academic advising and provision of physical facilities in the pursuit of satisfactory academic performance and excellence in the various departments, units and faculties of our tertiary institutions satisfaction with regards to the service delivery in universities in south eastern Nigeria.

It is of great importance that the teaching quality is significantly high, since competition to attract, maintain and foster students amongst universities are fierce today. A good university should be judged by its ability to plan and recruit brilliant academic staff who can perform well in all aspects, who understand the purpose for which the institution exist and agree to serve to its expectation (Smith, 1996). Deeper understandings of the nature of student learning, and pressures to reposition the teaching and learning environment around learning outcomes, demand a more professional approach to university teaching. The quality of teaching staff has direct correlation with student satisfaction (Sepideh, Hadi, \& Mona, 2013). Students are usually satisfied with the outcome of a lecture in class when such lecture helps them to gain more information, improves their abilities, and provides tutor's feedback on evaluated work, accessibility of class notes and reading material.

Academic staff are being asked to meet the needs of more diverse student groups, teach at more flexible times and locations, master the use of information technology in teaching, design curricula around learning outcomes and across disciplines, teach in teams, subject their teaching to evaluation and develop and implement improvements, monitor and respond to the evaluations made by students and graduates, improve assessment and feedback, to meet employer needs, and to understand and use new theories of student learning. At the very least, these tasks places a huge demands on the time of academic staff. Similarly, research demands are increasing: to improve postgraduate supervision, publish or patent, establish links with industry, and attract grants (Adams, 2002). In the face of an ever-increasing array of expectations and growing complexity of work, it is inevitable that academic staff will have greater strengths in some areas than others, and that their interests and productivity will change over time.

Shortage of academic staff in most Nigerian universities has led to overloading of those available leading to low service delivery. Most academic staff neglect their responsibilities, poorly plan their lectures, betray the academic trust in assessment and are slow in modernizing teaching and learning (Kasozi, 2009). Focusing on the role of academic staff on service delivery efficiency, Fielden (1998) points out that, to achieve service delivery efficiency, academic staff must possess various competences. Academic staff in their teaching role faces probably the biggest set of challenges to their working patterns. They bear the ultimate burden of having to "do more with less", as student numbers increase without matching funding. They are being asked to teach a wider range of students (mature, disadvantaged, part time etc.) in different ways involving new methods and technologies. Their accountabilities are being sharpened and made explicit, as quality reviews and assessments examine what they do.

Quality teaching is the use of pedagogical techniques to produce learning outcomes for students. It involves several dimensions, including the effective design of curriculum and course content, a variety of learning contexts (including guided independent study, project-based learning, collaborative learning, experimentation, etc.), soliciting and using feedback, and effective assessment of learning outcomes (Hénard and Roseveare , 2012). The emphasis of most universities today is on the quality of teaching. One result is that well-structured lectures alone no longer meet the criteria for excellent teaching. Academic staff are expected to utilize creative techniques that effectively engage students and support learning. According to Adams (2002), universities expect academic staff to embrace new pedagogies including the use of technology, collaborative learning, simulations, and field experiences. Because students come from a variety of backgrounds, demonstrate various levels of motivation and diverse learning styles, and exhibit a wide assortment of career goals, academic staff are expected to address their multiple needs, without sacrificing academic rigor.

The curriculum is the planned and guided learning experiences and intended learning outcomes. It refers to defined and prescribed courses of study, which students must fulfill in order to attain certain level of education and covers subject /course content, type of educational programme, etc. Concern about the quality and relevance of university education, and learning experiences of individual learners is on the rise in Nigeria and other parts of the world. This comes as a result of growing recognition of the potentially powerful role of university education for growth. Quality education, according to Mosha (1997) is: "measured by the extent to which the training received from an institution enables the recipient to think clearly, independently and analytically to solve relevant societal problems in any given environment"(p.13). The general feeling in the face of the current economic recession is 
International Journal of Engineering Applied Sciences and Technology, 2019

Vol. 4, Issue 5, ISSN No. 2455-2143, Pages 100-107

Published Online September 2019 in IJEAST (http://www.ijeast.com)

that the quality of education imparted with curricula that are limited to parochial concerns may no longer be adequate. Any curriculum that has little relevance to the needs, aspirations and values of today's Nigeria has outlived its usefulness. In view of the competition in the academic field, the universities are trying to produce excellent service of optimal costs, and assuring quality in their services across-the-board. This is because the global challenge requires excellent students, wellrounded and articulate, with very good knowledge in their chosen fields and a good command on languages, cultures, and skillful in handling challenging situations.

Course quality and other curriculum-related issues connected with a university can effect on overall student satisfaction. Tessema and Ready (2012) found a positive correlation between a curriculum which provide numerous course offerings for their students and more options and choices for them it can make and student satisfaction. A curriculum which provides a variety of options for students to choose from connects them and relates directly to their interests and gives them opportunity to explore curricular materials in ways that connect what they learn to who they are and the world around them will certainly bring satisfaction. Building a meaning curriculum and streamlining its content is very expedient in bringing about student satisfaction.

Students in universities experience academic difficulties at the beginning of the semester. Some for various reasons have poor academic performance and are placed on warning, probation or suspension. Through regular contacts with students, the advisor gain meaningful insights into students academic, social, and personal experiences and needs, which he use to help students feel a part of the academic community, develop sound academic and career goals and ultimately become successful learners. Writing on advising students with unsatisfactory academic performance, Catalogue on Academic Advising (2010) stated that an unfortunate fact of academic life is that some students, for various reasons, have poor academic performance. Academic advising is a specialized aspect of teaching involving students and teachers. It a process which provides institutions with the opportunity to personalize education and to engage students in their own learning. Academic advising provides students with accurate information about academic progression and grade requirement (Henning (2007) and helps them to access resources that will enhance their ability to be academically successful as well as review, use available data about students' academic and educational needs, performance, aspirations and problems. Hagen and Jordan (2008) maintained that, students can develop their mature educational and career goals when academic consultation is provided effectively. Also it can increase their satisfaction and their learning outcomes. Effective and meaningful academic advising and counseling can increase the satisfaction of students and their learning outcomes.

Educational facilities are an integral part of the overall process of developing an effective educational system. They enable the skillful teacher to achieve a level of instructional effectiveness that far exceeds what is possible when they are not provided (Ogbodo, 2004). Availability of facilities does not only enhance good teaching practices but also facilitate learning thus enhancing the achievement of the aims and objectives for which the schools are established. The quality of education that our children receive bears direct relevance to the availability or lack physical facilities and overall atmosphere in which learning takes place. This implies that educational programmes and process are greatly influenced by the school plant. The school plant influences not only the kind of programme but the diversity of each programme and the entire school enrolment. According to Okpa (2015) the right kind of atmosphere required for effective teaching and learning is the one consisting of better buildings and teaching facilities. Such learning environment is to be carefully planned by a team of experts, implemented by serious minded professionals and maintained by an effective administrator. This is because provision of adequate facilities to work with, buildings, furniture, workshops, laboratories, equipment, materials, grounds, library services, technology facilities, and, lighting of the lecture halls, appearance of school buildings, design of lecture halls, and cleanliness of the campus lecture rooms, parking facilities, and comforting access classroom, sports and athletic facilities and infrastructural facilities that make teaching and learning in school setting possible (Okpa, 2009) and have a significant effect on students educational experience.

Quality service delivery ought to be the major for focus our educational development, hence this study is concerned with finding out how the quality of service delivery experience in our universities relate to students satisfaction.

\section{STATEMENT OF THE PROBLEM}

There is a mismatch between service package and customer expectations in most of our institutions. This is evident in enrolment decline as well as declines in funding, donations and other forms of resource support which seem to have threatened the existence of academic programmes in Universities. The universities are experiencing a down turn on students' enrolment in recent times. The universities seem to be struggling with how to attract, retain and maintain student enrollment at desired levels. The declines though, have been caused by several factors, such as economic downturn, 
government and institutional policies, and increasing competition in the education market. Like other educational institutions, the schools have attempted to solve the problem of decline by promoting or publicizing their programmes in order to reach prospective students. Their attempts have included marketing activities such as advertisements, product development and branding and imaging campaigns. Excellent school business managers understand the importance of improving customer satisfaction by focusing on how to maximize service delivery quality. This study is therefore concerned with finding out the relationship between quality service delivery and students' satisfaction in public universities in south eastern Nigeria.

\section{AIM AND OBJECTIVES OF THE STUDY}

The study is aimed at investigating the relationship between quality service delivery and students satisfaction in universities in south eastern Nigeria. The specific objectives are:

1. To find out the relationship between the quality of teaching and students' satisfaction

2. To determine how curriculum type relate to students' satisfaction

3. To ascertain the extent to which academic advising services relate to students' satisfaction

4. To investigate the relationship between the provision of physical facilities and students' satisfaction.

\section{RESEARCH QUESTIONS}

To achieve the objective of the study the following research questions were formulated:

1. How does quality of teaching relate to students' satisfaction?

2. How does curriculum type relate to students' satisfaction

3. To what extent does academic advising services relate to students' satisfaction

4. To what extent does provision of physical facilities relate to students' satisfaction

\section{HYPOTHESES}

The following hypotheses were stated to give direction to the study.

1. There is no significant relationship between teaching quality and students' satisfaction.

2. There is no significant relationship between curriculum and students' satisfaction
3. There is no significant relationship between academic advising services and students' satisfaction

4. There is no significant relationship between physical facilities and students' satisfaction.

\section{METHODOLOGY}

This study adopted the descriptive survey design with a population of 1,231 students from Faculty of Education University of Calabar and Cross River University of Technology. Simple random sampling technique was adopted in selecting sixty (140) and forty (60) final year students respectively from the two universities making a total of one hundred respondents. The instrument that guided the study was questionnaire tagged: Quality Service Delivery and Students Satisfaction Questionnaire (QSDSQ). The instrument had two sections. Section elicited information on such variables as sex, age, class, school, faculty, and department. Section B contained 20 items assessed on a 4-point Likert scale (from $1=$ "Very satisfied" to $5=$ "Very dissatisfied"). The statements included in the questionnaire were clearly stated and aimed at obtaining the needed information about the students' level of satisfaction from the university services (in terms of quality teaching, curriculum, academic advising and availability of physical facilities). This scale collects students' opinions with understanding that 5 is the highest rate and 1 the lowest. Validity conditions were guaranteed first by subjecting the questionnaire through a subject-matter expert content validation involving three senior lecturers in the faculty of education and to a pilot study using 40 students that were not part of the final study. As for its reliability, Cronbach's alpha internal reliability index was used. The internal consistency coefficients obtained turned out to be considerably high. The reliability value stood at $r=0.72$. Pearson Product Moment Correlation statistics was used to test all the hypotheses generated for the study at $\mathrm{p}<0.05$ level of significance.

\section{RESULTS}

Table 1 Mean and standard deviation scores and Pearson Product Moment Correlation analysis of relationship between quality service delivery and students' satisfaction

\begin{tabular}{lccccccc}
\hline Variables & $\mathrm{N}$ & $\bar{x}$ & $\mathrm{SD}$ & $\mathrm{df}$ & $\begin{array}{l}\mathrm{r}- \\
\mathrm{cal}\end{array}$ & $\mathrm{r}-\mathrm{tab}$ & $\mathrm{p}$ \\
\hline Teaching & & 26. & 4.0 & & 0.6 & & \\
quality & & 60 & 2 & & 47 & & \\
Curriculum & 200 & 14. & 2.2 & 98 & 0.5 & 0.19 & 0.05 \\
& & 26 & 1 & & 62 & 5 &
\end{tabular}


International Journal of Engineering Applied Sciences and Technology, 2019

Vol. 4, Issue 5, ISSN No. 2455-2143, Pages 100-107

Published Online September 2019 in IJEAST (http://www.ijeast.com)

$\begin{array}{llll}\text { Academic } & 12 . & 2.3 & 0.5 \\ \text { advising } & 94 & 2 & 84 \\ \text { Physical } & 12 . & 2.1 & 0.5 \\ \text { facilities } & 61 & 2 & 92 \\ \text { Students } & 15 . & 2.0 & \\ \text { satisfaction } & 65 & 8 & \end{array}$

$\mathrm{P}<0.05$

The result presented on the above table shows that the range of the means ( $\bar{x}$ ) for variables (independent) is from 12.61 to 26.60 , whereas the standard deviations ranges from 2.12 to 4.04. the means and standard deviation of the dependent variable was 15.65 and 2.08. the low values of the standard deviation (SD) are indications of homogeneity among the respondents. Hence the research findings from these data could be relied upon and generalizations could be accepted with minimal error. A closer examination of the table shows that among the first four variables teaching quality has the highest mean $(\bar{x}=26.60, \mathrm{SD}=4.02)$ which is an indication that respondents have high concern for teaching quality for their satisfaction. Whereas the rating for curriculum is very low ( $\bar{x}=14.26,2.21)$. The table also shows that to the calculated r-value of 0.647 for teaching quality, 0.562 for curriculum, 0.584 for academic advising, and 0.592 for physical facilities were found to be higher than the critical table value of 0.195 when tested at .05 level of significance. This implies that the result is significant, hence quality service delivery have a strong positive relationship with students' satisfaction in public universities.

\section{DISCUSSION}

The study investigated the relationship between quality service delivery and students' satisfaction in public universities in South Eastern Nigeria. Data obtained was analyzed using Pearson Product Moment Correlation coefficient. The result of hypothesis one revealed that there is a significant relationship between teaching quality and students' satisfaction. This result agrees with findings of Sepideh, Hadi and Mona, (2013) that the quality of teaching staff have direct correlation with student satisfaction. They explained that students experience satisfaction when the outcome of a lecture help them to gain more information, improves their abilities, provides tutor's feedback on evaluated work. The result of hypothesis two revealed that curriculum offering has significant positive relationship with students' satisfaction. This result agrees with the result of Tessema and Ready (2012) which found a positive correlation between a curriculum which provide numerous course offerings and student satisfaction. This is because a curriculum which provides a variety of options for students to choose from connects them and relates directly to their interests and brings satisfaction. The result of hypothesis three revealed a significant positive relationship between academic advising and students' satisfaction. This result corroborates with Hagen and Jordan (2008), result that effective academic advising and increase students satisfaction and learning outcomes.

The result of hypothesis four indicated that physical facilities have a significant positive correlation with students' satisfaction. This result is in line with Okpa (2009) view that provision of adequate facilities to work with makes teaching and learning in school setting possible and has significant effect on students' educational experience. This is because the quality of education offered to students' bears direct relevance to the availability or lack physical facilities and overall atmosphere in which learning takes place. This implies that educational programmes and process are greatly influenced by the school plant.

The above findings are of practical benefits to the universities because it provided them with relevant information about the importance of service delivery quality on students' satisfaction. The result has also created awareness in the minds of school administrators about the ways student enrolment and retention can be achieved in our institutions.

\section{CONCLUSION}

The need for quality service delivery in our tertiary institutions cannot be overemphasized, in view of constant hue and cry over dwindling academic standards and poor students' performances. It obvious from the result of the study that, lack quality service delivery results in high rate of dropouts, reduction in enrolment and retention and poor academic achievement. This study concludes that there is a significant relationship between service delivery quality and students satisfaction in public universities.

\section{RECOMMENDATIONS}

Based on the findings of the study the following recommendations were made:

1. Quality education is an imperative for the product of Nigerian university system so that they can cope effectively with contemporary demands of the society. The achievement of these objectives requires the university management to ensure that competent academic staff are appointed to academic 
positions. Also, academic staff in public universities should be provided with pedagogical training adequate for their assignment and to enhance their commitment to the teaching and learning delivery and to make them adaptable to changing conditions. There should be more school-based in-service workshops, seminars and training programmes to sharpen skills of lecturers and arm them with knowledge of fundamental concepts in teaching.

2. The universities should evolve and create a system of academic advising that is in line with the objectives of tertiary institutions to provide effective academic learning and develop performance skills in students, especially for those who encounter academic difficulties.

3. The need for periodic review of the school curriculum is highly desirable. The universities should ensure that the curriculum content is relevant to the needs of the individuals students, the society and the nature of the discipline.

4. University management should be more proactive towards infrastructural development and in providing adequate facilities for students to enhance their work as well as create good learning environment.

\section{ACKNOWLEDGEMENT}

The author gratefully acknowledge all those who participated this study in terms of providing the necessary information and all authors whose works were cited to enriched this study and that are responsible for whatever merit this paper has.

\section{REFERENCES}

1. Adams, K.A. (2002). What colleges and universities want in new faculty. Washington, DC: Association of American Colleges \& Universities.

2. Elliot, K.M. \& Shin, D. (2002). Student satisfaction an alternation approach to assessing the important concept. Journal of Higher Education Policy and Management, 24:2, 197-209.

3. Fielden, J. (1998).Higher education staff development: A continuing mission. Paris: August Thematic Debate Commonwealth Secretariat.

4. Green, P. \& Ramroop, S. (2014). Prioritizing Factors Influencing Service Quality at Durban
University of Technology: AHP Approach. Journal of Social Science, 40(2), 243-250.

5. Hagen, P. L. \& Jordan, P. (2008). Theoretical foundations of academic advising. Academic advising: A comprehensive handbook, 2, 17-35.

6. Henard, F. \& Roseveare, D. (2012). Fostering quality teaching in higher education: Policies and practices. OECD Publishing.

7. Henning, M. (2007). Students' Motivation to Learn, Academic Achievement, and Academic Advising: A Doctor of Philosophy thesis submitted to AUT University.

8. Kasozi, A.B.K.(2009). The plight and failure of academic staff in universities. Paper presented at public lecture in Kampala.

9. Mosha, H. (1997). Quality training and research in higher education. In J. Shabani (Ed), Higher Education in the $21^{\text {st }}$ century. Proceedings of a consultative meeting, Nairobi, Kenya 12 - 14 February 1997.

10. Ogbodo, C.M. (2004). Managing educational facilities in schools. In V.F. Peretomode 9ed0. Introduction to educational administration and planning and supervision. Ikeja: Joja Education Research and Publishers.

11. Okpa, O. E. (2009). School plant administration and teachers' job effectiveness in secondary school in central senatorial district, Cross River State. Unpublished M. Ed thesis, Faculty of Education, University of Calabar, Nigeria.

12. Okpa, O.E. (2015). Incentives and academic staff service delivery efficiency in universities in south south Nigeria. Unpublished PhD Dissertation, Faculty of Education, University of Calabar.

13. Parasuraman, A., Zeithaml, V.A., \& Berry, L.L. (1985). A conceptual model of service quality and its implications for future research. Journal of Marketing, 49, 41-50.

14. Pupo, R. (2010). America's service meltdown: Restoring service excellence in the age of the customer. Oxford: Praeger.

15. Sepideh, F. Hadi, M. \& Mona, A. 2013) Perceived service quality and student satisfaction in higher education. IOSR Journal of Business and Management (IOSR-JBM) eISSN: 2278-487X, p-ISSN: 2319-7668. 12, (4). 65-74.

16. Scott, D. (2003). Retention, completion and progression in tertiary education. Wellington: Ministry of Education.

17. Slaymaker, T., Christiansen, K. \& Hemming, I. (2005). Community-based approaches and 
service delivery: Issues and options in difficult environments and partnerships. Overseas Development Institute, February.

18. Smith, R. N. (1996). The making of a university to a nation. Cambridge Mass: Harvard University Press.

19. Soludo, C. C. (2013, January 15). The university citizenship and national transformation in Nigeria. Daily Sun, p.35.

20. Tait, M. \& de Jager, J. W. (2009). Image and academic expectations of different levels of university students: A South African case. South African Journal of Higher Education, 23(5), 1026-1038.

21. Tessema, M. T. \& Ready, K. (2012). Factors affecting college students' satisfaction with major curriculum: Evidence from Nine Years of Data.

22. Van der Westhuizen, 2014). Van der Westhuizen, E. J. (2014). Student experiences of service delivery in an academic department at a higher education institution in South Africa. Journal of Public Administration, 49 (1), 405-422.

23. Zeithaml (1988) Zeithaml, V.A. (1988). Consumer perceptions of price, quality and value: A mean-end model and synthesis of evidence. Journal of Marketing, 52, 2-22. 